UDC 664.951.4:637.5'82; 637.5'82:641.12

COBISS.SR-ID: 219342348

Original research paper

Acta Agriculturae Serbica, Vol. XX, 39 (2015);67-74

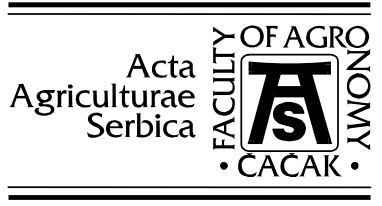

\title{
Total protein and lipid contents of canned fish on the Serbian market
}

\author{
Goran Marković, Jelena Mladenović, Milica Cvijović, Jelena Miljković \\ University of Kragujevac, Faculty of Agronomy, Cara Dušana 34, 32000 Čačak, \\ Serbia
}

\begin{abstract}
Total protein and lipid contents were analysed in 5 samples of canned fish (sardines, Atlantic mackerel fillets, tuna in olive oil, smoked Baltic sprat and herring fillets) available on the Serbian market. Standard methods for the determination of protein (Kjeldahl method) and lipid (Soxhlet method) contents were used on drained samples. The protein content was $21.31 \%$ on average, with a range of $18.59 \%-24.17 \%$. Total lipids showed considerably large variations $(5.49 \%-35.20 \%)$, and averaged $18.88 \%$. The observed differences, particularly in lipid content, were due to different fish species - the highest values were found in the meat of pelagic fish from northern seas (herring), but were also associated with the preservation (canning) technology used.
\end{abstract}

Key words: canned fish, proteins, lipids, Serbian market.

Received: 7 September 2015 / Accepted: 1 November 2015 
Acta Agriculturae Serbica, Vol. XX, 39 (2015); 67 - 74

\section{Introduction}

Modern humans obtain about $15 \%$ of their total animal protein intake from fish (Baltić et al. 2009). The global average per capita fish consumption is 18.6 $\mathrm{kg}$ (Anonymous 2012). Fish consumption in Serbia is considerably lower i.e. it is estimated at 4-6 kg per capita. This fact is due to underdeveloped food culture, reduced purchasing power of the population and insufficient fish production from aquaculture (Marković et al. 2011).

Fish is a source of readily digestible and biologically highly valuable nutrients. Apart from the high protein content and the favourable amino acid profile, fish meat has substantial levels of mono- and polyunsaturated fatty acids, minerals and vitamins (Vladau et al. 2008). Due to a low amount of connective tissue, fish exhibits a higher digestibility coefficient compared to the meat of other farm animals (Ababouch 2005). These properties impart a high nutritional value to fish meat, thus making it an important foodstuff for proper human nutrition (Ćirković et al. 2002).

The high water content $(75 \%-80 \%)$ renders fish meat susceptible to rapid decay (Vereš 2004). Fish preservation methods have been devised for centuries. In addition to traditional methods, modern consumer requirements have led to the development of a range of products that have an extended shelf life and a partially modified chemical composition.

Therefore, analyses of fish meat and fish products, particularly canned fish, are of great practical importance.

\section{Materials and methods}

Canned fish is the most common fish product in Serbia. Five random samples of canned fish available on the Serbian market were used for the analysis i.e. sardines in sunflower oil ("EVA" Podravka, Croatia), Atlantic mackerel fillets in sunflower oil ("Ocean Fish", Bulgaria), tuna in olive oil ("Thai Union Manufacturing" Co. Ltd., Thailand), smoked Baltic sprat ("Роскон”, Russia) and herring fillets in sunflower oil ("Karavela" Ltd., Latvia).

Prior to total protein and lipid content determination, gross weight (contents) of each can was measured on a technical scale. As the samples were canned in vegetable oil (sunflower oil, except olive oil for tuna), vegetable oil was drained and net weight of fish was measured. Drained fish samples were analysed for total proteins (Kjeldahl method) and lipids (Soxhlet method) (Čeković 1995). 
Acta Agriculturae Serbica, Vol. XX, 39 (2015); 67 - 74

\section{Results and Discussion}

Gross weight measurements of canned fish indicate sample heterogeneity. Total (gross) weight varied from 109.44 - $162.53 \mathrm{~g}$, whereas net (drained) weight was 75.04 - 131.93g (Table 1). The differences were due to commercial packaging. The average content of vegetable oil accounted for $29.41 \%$ of total net weight, and showed large variations $(19.00-40.38 \%)$. The low oil content in cans of Baltic sprat was due to the use of smoking as a fish preservation method. The low content of oil in cans of tuna, compared to the average oil content in all samples, is attributed to the fact that the use of olive oil is commercially less cost-effective. The manufacturer probably used the minimum amount of olive oil required to ensure the desired effect.

Table 1. Weight of the contents of fish cans

\begin{tabular}{|c|c|c|c|c|}
\hline TYPE OF CANNED FISH & $\begin{array}{l}\text { Gross } \\
\text { weight of } \\
\text { the } \\
\text { contents }(\mathrm{g})\end{array}$ & $\begin{array}{l}\quad \text { Net } \\
\text { (drained) } \\
\text { weight * }(\mathrm{g})\end{array}$ & $\begin{array}{r}\text { Weight } \\
\text { as a per } \\
\text { total co } \\
\quad(\mathrm{g})\end{array}$ & $\begin{array}{l}\text { vegetable oil } \\
\text { tage of the } \\
\text { ats * } \\
(\%)\end{array}$ \\
\hline 1. Sardines & 109.44 & 75.04 & 34.40 & 31.43 \\
\hline 2. Atlantic mackerel fillets & 110.62 & 73.80 & 36.82 & 33.28 \\
\hline 3. Tuna in olive oil & 157.21 & 121.15 & 36.06 & 22.94 \\
\hline 4. Smoked Baltic sprat & 162.53 & 131.93 & 30.88 & 19.00 \\
\hline 5. Herring fillets & 157.27 & 93.76 & 63.51 & 40.38 \\
\hline
\end{tabular}

* The results are not completely referenceable - the draining operation did not result in thorough elimination of vegetable oils from the samples.

The summarised results of the percentage of total proteins and lipids in canned fish samples show large differences in the content of these major organic components of fish meat (Table 2). Protein and lipid contents in fish meat vary across fish species, environments, age, catch season, type of diet, and other factors. Moreover, these biological quality parameters in canned fish are also affected by chemical composition, amount of preservatives (oils, salt...), thermal processing conditions, and type of dressing - parts of fish used in canning. 
Acta Agriculturae Serbica, Vol. XX, 39 (2015); 67 - 74

Table 2. Protein and lipid contents of drained fish meat of the tested samples

\begin{tabular}{llc}
\hline $\begin{array}{c}\text { TYPE OF CANNED } \\
\text { FISH }\end{array}$ & PROTEIN (\%) & LIPIDS (\%) \\
\hline 1. Sardines & 18.59 & 9.42 \\
2. Atlantic mackerel & 24.17 & 24.51 \\
3. Tuna & 21.55 & 19.77 \\
4. Baltic sprat & 20.78 & 5.49 \\
5. Herring & 21.44 & 35.20 \\
\hline
\end{tabular}

Protein content is an important quality indicator of fish meat, particularly in terms of its higher digestibility compared to the meat of warm-blooded animals that is widely used in human diet. The protein content of the tested samples was $21.31 \%$ on average, with a narrow range of $18.59-24.17 \%$. These values satisfy the criteria specified for high-quality animal products.

The lipid content of the tested samples accounted for an average of $18.88 \%$ of the total fish meat weight, and ranged widely from 5.49-35.20\%. The lowest values were determined in Baltic sprat meat, as the result of the smoking process. The highest values were found in herring fillets $(35.20 \%)$. This value confirms that pelagic fish from cold seas are an exceptional source of lipids, particularly polyunsaturated fatty acids which are of high quality and importance to human health (Ćirković et al. 2002). Unfortunately, the research did not involve analysing the qualitative and quantitative presence of individual fatty acids. The lower fat content in sardine meat suggests a somewhat lower nutritional value of this species compared to the other representatives of pelagic fish (primarily Atlantic mackerel and tuna).

As canned sardine, Atlantic mackerel and tuna are the most commonly consumed canned fish in Serbia, the data on protein and lipid contents were compared with reference data.

The results on canned sardine and Atlantic mackerel were compared with the results on these two types of canned fish present on the Montenegrin market (Đuričković et al. 2011).

Đuričković et al. (2011) analysed protein and lipid contents in homogenised samples with and without oil (drained). The protein contents of fish meat in the sardine samples of the present study $(18.59 \%)$ and in those from Montenegro (19.25\% in homogenised samples and 18.6 in drained samples) were uniform. The results suggest that the content of oil used as a preservative has no considerable effect on total protein content in fish meat. The fat content in our sample $(9.42 \%)$ was considerably lower than in samples on the Montenegrin market $(23.9 \%$ and $17.7 \%)$. A possible explanation lies in the fact that the sample 
in our study was subjected to intense drainage, while the method of preparation of the Montenegrin sample was unknown. Moreover, the geographical origin of the tested fish samples was unknown, while the sample used in our study was produced by a renowned manufacturer from Croatia.

The values for the protein content of Atlantic mackerel fillet $(24.17 \%)$ were approximate to Montenegrin ones $(25.33 \%$ and $23.73 \%)$. Like in sardines, the protein content of the same type of canned fish did not show large variations and was not greatly affected by the geographical origin of the main raw material (fish). The lipid content of Atlantic mackerel fillet in this study (24.51\%) was somewhat lower than in the homogenised sample (34.2\%), and higher than in the drained sample $(21.2 \%)$ from the Montenegrin market. These values show that total lipids in fish meat are largely affected by the amount of vegetable oil in the can, and whether the analysis is preceded by draining.

The protein and lipid contents of canned tuna in the present study comply with reference values (Aberoumand 2011).

The analysis of canned fish present on the Serbian market shows its satisfactory content of total proteins and lipids. This primarily refers to the high uniform content of proteins. The lipid content of fish meat is subject to wide variations, and results from the effect of most of the abovementioned factors.

The fact that both the cans and the raw materials are imported from different manufacturers and produced using different technologies requires their ongoing control. In addition to analysing the content of major organic and inorganic ingredients of fish, analyses should be expanded to involve determination of the levels of pesticides, heavy metals, mineral oils, detergents and other potentially dangerous substances, since raw materials used for the manufacture of these products may originate from contaminated aquatic environments. The presence of toxicants in water as well as in planktonic and other organisms eaten by fish may lead to their accumulation in fish and pose potential danger to consumers.

\section{Conclusion}

Fish is a source of readily digestible and biologically highly valuable nutrients. The high water content renders fish meat susceptible to rapid decay. Therefore, different preservation techniques such as canning are used.

Five samples of canned fish (sardines, Atlantic mackerel fillets, tuna in olive oil, smoked Baltic sprat and herring fillets) available on the Serbian market were used in the analysis. The drained fish samples were evaluated for total protein and lipid contents.

The protein content of the tested samples was $21.31 \%$ on average, with a narrow range of $18.59-24.17 \%$. The lipid content averaged $18.88 \%$, and ranged widely from $5.49-35.20 \%$. The observed differences, particularly in lipid content, were due to different fish species - the highest values were found in the meat of 
Acta Agriculturae Serbica, Vol. XX, 39 (2015); 67 - 74

pelagic fish from northern seas (herring), but were also associated with the preservation (canning) technology used.

The analysis of canned fish present on the Serbian market shows its satisfactory content of total proteins and lipids. This primarily refers to the high uniform protein content. However, a complex evaluation of canned fish quality requires the expansion of the analysis of nutritional components to involve determination of the presence of potentially toxic substances.

Acknowledgements: This work was financed by the Ministry of Education and Science, Republic of Serbia (Grant No. 31011).

\section{References}

$\mathrm{A} \mathrm{b}$ a b o u c h L. (2005): Nutritional elements of fish. FAO Fisheries and Aquaculture Department www://fao.org/fishery/topic/12319/en.

A b e r o u m a n d A. (2011): Proximate Composition and Energy Values of Canned Tuna Fish Obtained from Iran. Middle-East Journal of Scientific Research, 9(4): 442-446.

Anonymous (2012): The State of World Fisheries and Aquaculture. FAO Rome www://fao.org.

B a 1 t i ć Ž.Z, K i l i b a r d a N., D i m i t r i j e v i ć M. (2009): Činioci od značaja za održivost ribe i odabranih proizvoda od ribe u prometu. Tehnologija mesa, 50(12):166-176.

Č e k o v i ć Ž. (1995): Eksperimentalna organska hemija. Hemijski fakultet, Beograd.

Ć i r k ovi ć M., J ov a novi ć B., M a l e t i n S. (2002): Ribarstvo. Poljoprivredni fakultet, Novi Sad.

M a r k ov ić Z., S t a n k ov i ć M., D u 1 i ć Z., Ž i vi ć I., R a š k o vi ć B., S p a s i ć M., Poleksić V. (2011): Aquaculture and fishery in Serbia - status and potential. $V$ International Conference "Aquaculture \& Fishery", Faculty of Agriculture, Belgrade-Zemun, 36-40.

Đ u r i č k o v i ć M., M a l i š i ć N., J o v i ć e v i ć Lj., N e d i ć A. (2011): Hemijska analiza ribljih konzervi. Hrana i ishrana, 52(2): 42-48.

V e r e š M. (2004): Principi konzervisanja namirnica. Poljoprivredni fakultet, Beograd.

V 1 a d a u V.V., B u d I., R e k a S. (2008): Nutritive value of fish meat comparative to some animals meat. Bulletin UASVM Animal Science and Biotechnologies, 65(1-2): 301-304. 
Acta Agriculturae Serbica, Vol. XX, 39 (2015); 67 - 74

\title{
UKUPAN SADRŽAJ PROTEINA I LIPIDA U NEKIM RIBLJIM KONZERVAMA NA TRŽIŠTU SRBIJE
}

\author{
Goran Marković, Jelena Mladenović, Milica Cvijović, Jelena Miljković \\ Univerzitet u Kragujevcu, Agronomski fakultet, Cara Dušana 34, 32000 Čačak, \\ Srbija
}

\section{Rezime}

Riblje meso predstavlja izvor lako svarljivih i biološki visoko vrednih nutritivnih sastojaka. Pored visokog sadržaja proteina i povoljnog aminokiselinskog odnosa, zbog manjeg sadržaja vezivnog tkiva meso riba ima veći koeficijent svarljivosti od mesa drugih domaćih životinja. Usled velike prisutnosti vode, riblje meso predstavlja namirnicu podložnu brzom kvarenju. Pored tradicionalnih proizvoda, usled zahteva savremenih potrošača, na tržištima postoji niz proizvoda koje odlikuje produženi rok upotrebe i delimično izmenjeni hemijski sastav. Zbog svega navedenog, analiza ribljeg mesa i ribljih prerađevina, posebno ribljih konzervi, ima veliki praktični značaj.

Izvršena je analiza ukupnog sadržaja proteina i lipida u 5 uzoraka ribljih konzervi (sardina, fileta skuše, tuna u maslinovom ulju, dimljenih papalina i fileta haringe) prisutnih na tržištu Srbije. Analiza je vršena standardnim postupcima određivanja sadržaja proteina metodom po Kjeldalu (Kjeldahl) i lipida metodom po Soksletu (Soxlet) na uzorcima koji su prethodno oceđeni. Prosečni sadržaj proteina je iznosio $21,31 \%$ uz variranja od $18,59 \%$ do $24,17 \%$. Prosečan sadržaj ukupnih masti u analiziranim uzorcima je bio $18,88 \%$ uz znatno veća variranja $(5,49 \%$ - 35,20\%). Uočene razlike, posebno u sadržaju masti, posledica su pripadnosti različitim vrstama riba - najveće vrednosti su registrovane u mesu plavih riba severnih mora (haringe) ali i od tehnološkog postupka izrade (načina konzervisanja).

Rezultati analize sadržaja proteina i lipida ribljeg mesa iz konzervi prisutnih na tržištu Srbije ukazuju da su one zadovoljavajućeg sadržaja. To se prvenstveno odnosi na visok i ujednačen sadržaj proteina. Međutim, za kompleksnu ocenu kvaliteta ribljih konzervi potrebno je vršiti proširene analize koje bi, pored određivanja nutritivnih komponenti, obuhvatile i analizu prisustva potencijalno toksičnih supstanci.

Ključne reči: riblje konzerve, proteini, lipidi, tržište Srbije 